\title{
Effect of the cross linkers' concentration on the immobilization of recombinant Escherichia coli cells on hollow fiber membrane for excretion of cyclodextrin glucanotransferase (CGTase)
}

\author{
R.CheMan ${ }_{2}{ }^{*}$ R. M. Illias, ${ }^{2}$ S. Z. Sulaiman, ${ }^{1}$ S. K. Abdul Mudalip, ${ }^{I}$ S.Md Shaarani, ${ }^{I}$ Z. I.Mohd. Arshad
}

\begin{abstract}
${ }^{1}$ Faculty of Chemical Engineering and Natural Resources, Universiti Malaysia Pahang, Lebuhraya TunRazak, 26300 Kuantan, Pahang, Malaysia. ${ }^{2}$ Department of Bioprocess Engineering, Faculty of Chemical and Energy Engineering, Universiti Teknologi Malaysia, 81310 Skudai, Johor, Malaysia. Article Info: Submitted on March 20, 2017, Accepted on June 20, 2017.

Abstract: The excretion of recombinant proteins into the culture medium is a preferred approach over cytoplasmic expression because of the high specific activity and ease of purification. However, cell lysis is one of a major problem during the excretion of recombinant protein due to the pressure build up in the periplasmic space through overproduction of the expressed recombinant protein. Cell immobilization is a promising solution for the improvement of protein excretion with reduction in cell lysis. In this study, the effect of cross linkers concentrations on the process of cell immobilization for the cyclodextringlucanotransferase (CGTase) excretion and cell viability were investigated. The hollow fiber membrane was treated using different concentrations $(0.3$, 0.67 and $1 \%$ ) of cross linkers namely glutaraldehyde (GA), poly-L-lysine (PLL) and polyethylenimine (PEI). The optimum concentration of cross linkers was found to be $0.3 \%$ with the high excretion of CGTase. Interestingly, the immobilized cell on the non-treated hollow fiber membrane showed up to $15 \%$ increment of CGTase excretion with 55\% reduction of cell lysis, as compared to the immobilized cells on the treated hollow fiber membrane. It could be concluded that, the low concentration of cross linkers exhibited the highest CGTase excretion. Moreover, the non-treated hollow fiber membrane is a promising approach for attachment of cells to the membrane without requiring treatment with any chemicals for the production of recombinant enzyme.
\end{abstract}

Keywords: Immobilized cell; CGTase excretion; Cell lysis; Cross linkers; Hollow fiber membrane.

\section{Introduction}

In recent years, there has been great interest in the production of heterologous proteins by utilizing recombinant DNA technology. Some of these heterologous proteins have already been produced at the industrial level. However, the recombinant protein products accumulate in the microorganisms especially when using Escherichia coli(E. coli) as a host. Therefore, the excretion of these proteins to the external medium would be attractive with regard to further downstream processing and the stability of the protein product. However, the excretion of heterologous proteins remains problematic. In $E$. coli, excretion always correlates with non-specific leakage and cell lysis. Thus, it becomes a challenge when the recombinant protein needs to be excreted with low cell lysis. Using the cell immobilization method, increased protein excretion with reduction in cell lysis can be achieved. The advantages for the use of immobilized cells include the preservation of plasmid-bearing cells, decreased risk of contamination and protection of the cells from environmental stresses $^{1-3}$. Therefore, the cell immobilization could reduce the occurrence of cell lysis.

Cross linking of immobilization support with chemicals is a common approach in order to strengthen the attachment of microbial cells to the solid support ${ }^{4}$ and to improve both mechanical and chemical stability of the support, resulting in better retention and higher viability of cell, thus improve the product formation ${ }^{5}$. Generally, cross linking of immobilization support with chemicals involve two steps, first activation of the support and secondly binding the cell to the activated support. The glutaraldehyde (GA), poly-L-lysine (PLL) and polyethyleneimine (PEI) are the most frequent cationic cross linking agents that are effectively used in immobilization system. However, the immobilization procedure using cross linking agent generally incompatible with cell viability since the cross-linkers were highly toxic to the microbial cells thus decreased the productivity ${ }^{6}$.

(OBangladesh Uni. of Engg.\&Tech 154 


\section{Chemical Engineering Research Bulletin 19(2017) 154-159}

According to Krastanov ${ }^{7}$, GA was the best cross linker for the immobilization of yeast cells on wool. However, Bishtet al. ${ }^{8}$ reported that the use of GA as a crosslinker exerted an adverse effect on immobilized $P$. aeruginosa entrapped in agarose for lipase production. Meanwhile, the treatment of supports with PEI enhanced the immobilization of cells to the bead ${ }^{9}$ and cotton ${ }^{10}$. Therefore, the choices of cross linkers with suitable concentration for cell immobilization are the significant factors affecting the product formation and long-term stability of immobilized cells.

In the present study, hollow fiber membrane was employed as the matrix for immobilization of E. coli for the excretion of cyclodextringlucanotransferase (CGTase) with a low occurrence of cell lysis. The cross linkers were used to strengthen the attachment of $E$. coli to the hollow fiber membranes. The effects of cross linkers' concentrations were studied to determine the optimum concentration for the high CGTase excretion with low cell lysis. To the best of our knowledge, there have been no studies on the effect of crosslinkers on the immobilization of recombinant $E$. coli using the hollow fiber membrane for the excretion of CGTase.

\section{Methodology}

\section{Bacterial strain and cell immobilization}

The recombinant E. coli strain carrying CGTasefrom Bacillus G1 was constructed previously by Jonet et al. ${ }^{11}$. E. coli JM109 strain and E. coli BL21 (DE3) strain were chosen to be the hosts for the cloning and expression, respectively. pET system from Novagen was used as the vector backbones for cloning. Hollow fiber membranes $(50 \mathrm{~cm})$, consist of polyvinylidene fluoride (PVDF) polymer, products from Advanced Membrane Technology Research Center (AMTEC), Universiti Teknologi Malaysia was chopped to the required size $(5 \mathrm{~cm}$ length) and then was sterilized at 15 psi $121^{\circ} \mathrm{C}$.

The effect of crosslinkers[glutaraldehyde (GA), polyL-lysine (PLL) and polyethyleneimine (PEI)] concentration on CGTase excretion and cell viability of the immobilized cell was studied using concentrations of $0.30,0.67$ and $1.00 \%$ based on the study conducted by Chu et al. ${ }^{12}$. The hollow fiber membranes were rinsed with the sterile distilled water and dried. Then, the dried hollow fiber membrane was soaked in the respective solution of the cross linkers at difference concentrations $(0.30,0.67$ and $1.00 \%)$ for 3 $\mathrm{h}$. The treated membranes was washed with sterile distilled water and transferred into $50 \mathrm{ml} \mathrm{LB}$ medium $(10 \mathrm{~g} / \mathrm{l}$ tryptone, $5 \mathrm{~g} / \mathrm{l}$ yeast extract, $5 \mathrm{~g} / \mathrm{l} \mathrm{NaCl})$ supplemented with $100 \mu \mathrm{g} / \mathrm{ml}$ ampicillin. The hollow fiber membrane was cultivated with cells from a glycerol stock at $37^{\circ} \mathrm{C}$ and $200 \mathrm{rpm}$. After $18 \mathrm{~h}$ (optimization time for cell immobilization), the membrane was thoroughly washed with the sterile water to eliminate the non-immobilized cells. The immobilized cells were then transferred to $250-\mathrm{ml}$ flasks containing $50 \mathrm{ml}$ of expression medium, namely super optimal broth, SOB ( $20 \mathrm{~g} / \mathrm{l}$ tryptone, $5 \mathrm{~g} / \mathrm{l}$ yeast extract, $0.5 \mathrm{~g} / \mathrm{l} \mathrm{NaCl}, 0.186 \mathrm{~g} / \mathrm{l} \mathrm{KCl}$ and $2.4 \mathrm{~g} / \mathrm{l} \mathrm{MgCl}_{2}$ ) supplemented with $100 \mu \mathrm{g} / \mathrm{ml}$ ampicillin. The expression was conducted using $0.011 \mathrm{mM}$ IPTG at $25^{\circ} \mathrm{C}$ and $200 \mathrm{rpm}$ until $24 \mathrm{~h}$ of post induction time.

The un-treated hollow fiber membrane was used as a control in the experiment and has the same growth and expression conditions with the treated hollow fiber membrane.

\section{Analytical methods}

CGTase activity was determined using the phenolphthalein assay ${ }^{13}$. One milliliter of substrate buffer containing $40 \mathrm{mg} / \mathrm{ml}$ soluble starch in $0.1 \mathrm{M}$ phosphate buffer, $\mathrm{pH} 6.0$ was added to $0.1 \mathrm{ml}$ protein sample and incubated at $60{ }^{\circ} \mathrm{C}$ for $10 \mathrm{~min}$. The reaction was terminated by the addition of $3.5 \mathrm{ml}$ of 30 $\mathrm{mM}$ sodium hydroxide. Then, $500 \mu \mathrm{l}$ of $0.02 \%$ (w/v) of phenolphthalein in $5 \mathrm{mM}$ sodium carbonate was added to the reaction mixture and incubated for $15 \mathrm{~min}$ at room temperature. The reduction in color intensity was measured at $550 \mathrm{~nm}$. One unit of enzyme activity was defined as the amount of enzyme that forms 1 $\mu$ mol of $\beta$-cyclodextrin from soluble starch per minute under the experimental condition.

Cell lysis was quantified by determining the amount of $\beta$-galactosidase in the extracellular medium using 0 nitrophenyl- $\beta$-D-galactopyranosid (ONPG). A total of $1 \mathrm{ml}$ of substrate buffer containing $4 \mathrm{mg} / \mathrm{ml}$ of ONPG in $0.1 \mathrm{M}$ phosphate buffer ( $\mathrm{pH}$ 7.4) was added with 0.1 $\mathrm{ml}$ of sample before it was incubated in $37^{\circ} \mathrm{C}$ water bath for $10 \mathrm{~min}$. The reaction was stopped by adding $0.5 \mathrm{ml}$ of $1 \mathrm{M}$ sodium carbonate and the absorbance was read at $420 \mathrm{~nm}$. One unit of enzyme activity was defined as the amount of enzyme that forms $10^{-8}$ moles of ONP per min under the experimental condition.

\section{Results and Discussions}

Cross linking of the immobilization matrix with a cross linker is a common approach in order to strengthen the attachment of microbial cells to the matrix ${ }^{4}$. In this study, the treatment of hollow fiber membrane with crosslinking agents was conducted to improve the binding capacity and strengthen the attachment of the cells to the hollow fiber membrane because there are high possibilities of cells detachment during the expression. The glutaraldehyde (GA), poly-L-lysine 


\section{Chemical Engineering Research Bulletin 19(2017) 154-159}

(PLL) and polyethyleneimine (PEI) are the frequent cationic crosslinking agents that are effectively used in the immobilization system ${ }^{9}$.

The hollow fiber membrane was treated using different concentrations $(0.3,0.67$ and $1 \%)$ of cross linkers (GA, PLL and PEI). The expression of immobilized cell using treated membrane was conducted at $25^{\circ} \mathrm{C}, 0.011$ $\mathrm{mM}$ IPTG and $\mathrm{pH} 8.8$ until $24 \mathrm{~h}$ of post induction time. As shown in Figure 1, the hollow fiber membrane treated with $0.3 \%$ crosslinkers exhibited the highest CGTase excretion compared to other concentrations, in which the PEI demonstrated the highest CGTase excretion with $785.73 \mathrm{U} / \mathrm{ml}$ of CGTase activity, followed by GA $(748.21 \mathrm{U} / \mathrm{ml})$ and PLL $(728.94 \mathrm{U} / \mathrm{ml})$. Helanderet al. ${ }^{14}$ stated that PEI increased the permeability of the outer membrane of gram-negative bacteria. As the permeability of the outer membrane increased, the CGTase excretion to the extracellular medium was also improved.

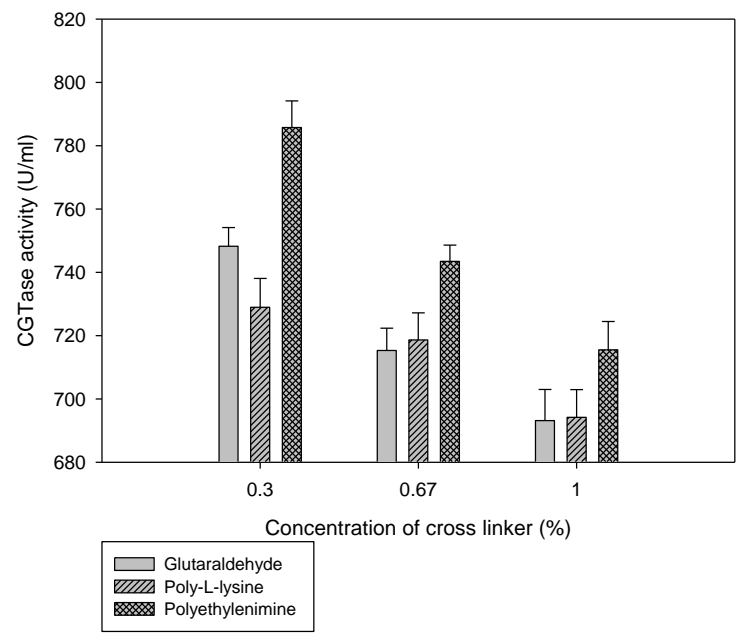

Figure 1: Effect of cross linkers (GA, PLL and PEI) concentration on CGTase excretion of the immobilized cell. The expression of immobilized cell using treated membrane was conducted at $25^{\circ} \mathrm{C}, 0.011 \mathrm{mM}$ IPTG and $\mathrm{pH}$ 8.8. The enzyme activity was measured after $24 \mathrm{~h}$ of post induction time.

It was observed that higher concentrations of cross linkers (GA, PLL and PEI) significantly reduced the CGTase excretion. The CGTase excretion was decreased to $739.44 \mathrm{U} / \mathrm{ml}, 718.61 \mathrm{U} / \mathrm{ml}$ and 715.31 $\mathrm{U} / \mathrm{ml}$ when the hollow fiber membrane was treated with $0.67 \%$ PEI, PLL and GA, respectively. Meanwhile, $1 \%$ of crosslinkers showed the lowest As illustrated in Figure 2, the $\beta$-galactosidase activity of the immobilized cell decreased as the concentration of PEI increased. The $\beta$-galactosidase activity was $33.81 \mathrm{U} / \mathrm{ml}$ at $0.3 \%$ PEI and $20.34 \mathrm{U} / \mathrm{ml}$ at $1 \%$ PEI. The high concentration of PEI was reported to affect the cells in a negative sense ${ }^{17}$ due to the precipitation of PEI in huge cluster that adhered to the cell surface. excretion of CGTase with $715.51 \mathrm{U} / \mathrm{ml}$ of CGTase activity using PEI-treated membrane, $694.18 \mathrm{U} / \mathrm{ml}$ of CGTase activity using PLL-treated membrane and $693.14 \mathrm{U} / \mathrm{ml}$ of CGTase activity using GA-treated membrane. The decrease of CGTase excretion was the result of the high concentration of crosslinkers that adversely affected the viability of the immobilized cells $^{6}$. The high concentration of crosslinkers would bind to the outer cell surface ${ }^{15}$ and potentially block or seal the outer membrane of the cells ${ }^{16}$.

This phenomenon effectively prevented or decreased the access of substrate and oxygen to the cells. Moreover, the high concentration of crosslinkers penetrated into the cytoplasmic membrane and acted directly with the cell system ${ }^{15}$, thus affected the cell viability. As shown in Figure 2, the high level of $\beta$ galactosidase in the culture medium indicated that the high concentration of crosslinkers caused detrimental effect on the immobilized cell. The $\beta$-galactosidase activity increased up to $58 \%(41.27 \mathrm{U} / \mathrm{ml}$ of $\beta$ galactosidase activity) and $23 \%(24.64 \mathrm{U} / \mathrm{ml}$ of $\beta$ galactosidase activity) when $1 \%$ PLL and $1 \%$ GA were used as the cross linkers compared to $0.3 \%$ PLL and $0.3 \% \mathrm{GA}$, respectively.

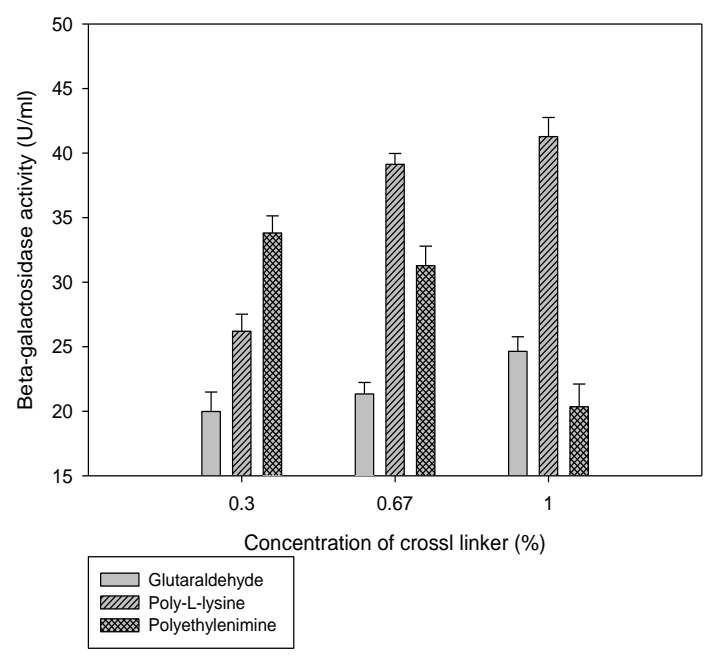

Figure 2: Effect of cross linkers (GA, PLL and PEI) concentration on $\beta$-galactosidase activity (indicator of cell lysis) of the immobilized cell. The expression of immobilized cell using treated membrane was conducted at $25^{\circ} \mathrm{C}, 0.011 \mathrm{mM}$ IPTG and $\mathrm{pH}$ 8.8. The enzyme activity was measured after $24 \mathrm{~h}$ of post induction time.

Insufficient nutrients transportation led to the retardation of cell replication. It is suggested that, low number of cells (due to the retardation of cell replication) on the hollow fiber membrane reduced the chances for cell lysis to occur. Therefore, $0.3 \%$ was selected as the optimal concentration of cross linkers (GA, PLL and PEI) for the stronger attachment of cell 


\section{Chemical Engineering Research Bulletin 19(2017) 154-159}

to the matrix because of the high CGTase excretion with low occurrence of cell lysis.

The hollow fiber membrane treated with $0.3 \%$ of cross linkers together with the non-treated membrane (as a control) was used to investigate the CGTase excretion and cell viability of the immobilized cells. The expression of immobilized cell was conducted at $25^{\circ} \mathrm{C}$ of post induction temperature, $0.011 \mathrm{mM}$ IPTG and $\mathrm{pH}$ 8.8. Table 1 shows the CGTase excretion of the immobilized cell using the non-treated and treated membrane. The highest CGTase activity of the immobilized cell was exhibited by the non-treated membrane $(819.19 \mathrm{U} / \mathrm{ml})$, followed by treated membrane with PEI (798.46 U/ml), GA $(753.72 \mathrm{U} / \mathrm{ml})$ and PLL (714.48 U/ml). The non-treated membrane displayed the highest CGTase excretion due to the effective interaction (three mechanisms of interactions which are two electrostatic interactions and a hydrophobic interaction) between the membrane and the cells ${ }^{18}$.

The PVDF hollow fiber membrane used in this study consists of hydrogen atoms (positively charged) and fluoride atoms (negatively charged) and behaves as a hydrophobic polymer ${ }^{19-20}$. In addition, most bacterial cell surfaces exhibit a net negative charge under common physiological conditions ${ }^{21-22}$. First, the E. coli cells were effectively adsorbed onto a PVDF membrane through the electrostatic interactions between the positively charged PVDF surfaces and the negatively charged cells. Second, the interactions between the positively charged domains on the cell surface and the negatively charged surface of membrane also contributed to another electrostatic interaction. The positively charged domains, which consist of unique combinations of polysaccharides, proteins, carbohydrates, DNA and lipids promoted the formation of biofilms ${ }^{23-25}$. Third, the hydrophobic interactions at a very close distance also significantly contributed to the cell adsorption onto a membrane ${ }^{26}$. However, when the membrane was treated with the cross linkers, the membrane surface became positively charged and interacted with the negatively charged cells. Therefore, the adsorption of E. coli on the treated membrane only involved electrostatic interactions between the negatively charged cells and the positively charged surfaces of membrane (one interaction)

As tabulated in Table 1, the un-treated hollow fiber membrane exhibited the lowest occurrence of cell lysis compared to the treated hollow fiber membrane with $15.30 \mathrm{U} / \mathrm{ml}$ of $\beta$-galactosidase activity. The findings could be due to detrimental effect caused by the crosslinkers on the cell system ${ }^{15}$, which in turn alter the expression characteristics that reduced the CGTase excretion and enhance the occurrence of cell lysis. compared three interactions that were responsible for the adsorption of $E$. coli on the non-treated membrane. It is suggested that, the strong attachment of cells to the non-treated membrane resulted in the highest CGTase excretion.

Table 1: CGTase activity and $\beta$-galactosidase activity of immobilized cells using non-treated and treated membrane.

\begin{tabular}{|l|l|l|}
\hline Cross linker & $\begin{array}{l}\text { CGTase } \\
\text { activity }(\mathrm{U} / \mathrm{ml})\end{array}$ & $\begin{array}{l}\beta \text {-galactosidase } \\
\text { activity }(\mathrm{U} / \mathrm{ml})\end{array}$ \\
\hline $\begin{array}{l}\text { Control } \\
\text { (Non-treated) }\end{array}$ & 819.19 & 15.30 \\
\hline GA & 753.72 & 26.33 \\
\hline PLL & 714.48 & 26.20 \\
\hline PEI & 798.46 & 33.81 \\
\hline
\end{tabular}

Kawagutiet $a .^{5}$ reported that the production of isomaltulose from immobilized Erwinia sp. D12 increased when calcium alginate beads treated with $0.06 \%$ of glutaraldehyde was used, which was contradicted to the finding of this study. It was found that the isomaltulose production increased because of the high cell retention and the high physical strength of the treated beads during fermentation compared to the non-treated beads. Moreover, Chu et al. ${ }^{12}$ reported that viscose fiber treated with $0.667 \%$ PEI was found capable of immobilizing the most viable recombinant E. coli. The PEI is a highly branched cationic polymer and has been widely used as a crosslinker to enhance the attachment of the cell to the matrix ${ }^{27}$. The interaction that occurred between the negatively charged cells to the positively charge PEI increased the attachment of the cell to the viscose fiber. However, the present study showed that the non-treated membrane produced higher CGTase excretion compared to the treated membrane may probably be due to the three mechanisms of interaction (two electrostatic interactions and a hydrophobic interaction) which were responsible for the effective attachment of $E$. coli cells to the PVDF membrane. Therefore, it could be concluded that the non-treated hollow fiber membrane is a promising approach for attachment of the cells to the membrane without requiring treatment with any chemicals for the production of recombinant enzyme.

\section{Conclusion}

The low concentration of crosslinkers leads to a significant excretion of CGTase with the high cell viability. Interestingly, the immobilized cells on the non-treated hollow fiber membrane showed the high CGTase excretion with reduction of cell lysis compared to the treated hollow fiber membrane. The 


\section{Chemical Engineering Research Bulletin 19(2017) 154-159}

approach using non-treated hollow fiber membrane demonstrated to be a promising strategy to produce more CGTase excretion especially during reusability process and will be valuable for the excretion of recombinant proteins in E. coli.

\section{Acknowledgement}

We are grateful to the Ministry of Higher Education (MOHE), Malaysia and Universiti Teknologi Malaysia (UTM).

\section{References}

1. C. Moriwaki, F.M. Pelissari, R.A.C. Gonçalves, J.E. Gonçalves, and G. Matioli, "Immobilization of Bacillus firmus strain 37 in inorganic matrix for cyclodextrin production," Journal of Molecular Catalysis B-Enzymatic, vol. 49, pp. 1-7, 2007.

2. G. Mamo, and A. Gessesse, "Thermostable amylase production by immobilized thermophilic Bacillus sp," Biotechnology Techniques,vol. 11,pp. 447-450, 1997.

3. R. Jamuna, and S. Ramakrishna, "Continuous synthesis of thermostable $\alpha$-amylase by Bacillus cells immobilized in calcium alginate," Enzyme and Microbial Technology, 14, pp. 36-41, 1992.

4. N. Atanasova, T. Kitayska, D. Yankov, M. Safarikova, and A. Tonkova, "Cyclodextrin glucanotransferase production by cell biocatalysts of alkaliphilic bacilli," Biochemical Engineering Journal, vol. 46, pp. 278-285, 2009.

5. H.Y. Kawaguti, M.F. Buzzato, D.C. Orsi, G.T. Suzuki, and H.H. Sato, "Effect of the additives polyethylenimine and glutaraldehyde on the immobilization of Erwinia sp. D12 cells in calcium alginate for isomaltulose production," Process Biochemistry,vol. 41, pp. 2035-2040, 2006.

6. G.A. Junter, and T. Jouenne, "Immobilized viable microbial cells: from the process to the proteome... or the cart before the horse,"Biotechnology Advances,vol. 22, pp. 633658, 2004.

7. A. Krastanov, "Continuous sucrose hydrolysis by yeast cells immobilized to wool," Applied Microbiology and Biotechnology,vol. 47, 476481,1997.

8. D. Bisht, S.K. Yadav, and N.S. Darmwal, "Optimization of immobilization conditions by conventional and statistical strategies for alkaline lipase production by Pseudomonas aeruginosa mutant cells: scale-up at bench-scale bioreactor level," Turkish Journal of Biology,vol. 37,pp. 392404, 2013.
9. A. Senthuran, V. Senthuran, B. Mattiasson, and R. Kaul, "Lactic acid fermentation in a recycle batch reactor using immobilized Lactobacillus casei," Biotechnologyand Bioengineering, 55, pp. 841853, 1997.

10. S. D'souza, and N. Kamath, "Cloth bioreactor containing yeast cells immobilized on cotton cloth using polythylenimine," Applied Microbiology and Biotechnology, vol. 29, pp. 136-140, 1988.

11. M.A. Jonet, N.M. Mahadi, A.M.A. Murad, A. Rabu, F.D.A. Bakar, R.A. Rahim, K.O. Low, and R.M. Illias, "Optimization of a heterologous signal peptide by site-directed mutagenesis for improved secretion of recombinant proteins in Escherichia coli," Journal of Molecular Microbiology and Biotechnology, vol. 22,pp. 48-58, 2012.

12. Y.F. Chu, C.H. Hsu, P.K. Soma, and Y.M. Lo, "Immobilization of bioluminescent Escherichia coli cells using natural and artificial fibers treated with polyethyleneimine," Bioresource Technology, vol. 100, pp. 3167-3174, 2009.

13. H.K. Sian, M. Said, O. Hassan, K. Kamaruddin, A.F. Ismail, R.A. Rahman, N.A.N. Mahmood, and R.M. Illias, "Purification and characterization of cyclodextrin glucanotransferase from alkalophilic Bacillus sp. G1," Process Biochemistry,vol. 40,pp. 1101-1111, 2005.

14. I.M. Helander, H.L. Alakomi, K. Latva-Kala, and P. Koski, "Polyethyleneimine is an effective permeabilizer of gram-negative bacteria," Microbiology, vol. 143, pp. 3193-3199, 1997.

15. T. Munton, and A. Russell, "Effect of glutaraldehyde on cell viability, triphenyltetrazolium reduction, oxygen uptake, and $\beta$-galactosidase activity in Escherichia coli," Applied Microbiology,vol. 26, pp. 508-511, 1973.

16. H. Kubitschek, "Constancy of uptake during the cell cycle in Escherichia coli," Biophysical Journal, vol. 8, pp. 1401, 1968.

17. D. Fischer, T. Bieber, Y. Li, H.P. Elsässer, and T. Kissel, "A novel non-viral vector for DNA delivery based on low molecular weight, branched polyethylenimine: effect of molecular weight on transfection efficiency and cytotoxicity," Pharmaceutical Research,vol. 16 , 1273-1279, 1997.

18. R.C. Man, A.F. Ismail, N.F. Ghazali, S.F.Z.M. Fuzi, and R.M. Illias, "Effects of the immobilization of recombinant Escherichia coli on cyclodextrin glucanotransferase (CGTase) excretion and cell viability," Biochemical Engineering Journal, vol. 98, pp. 91-98, 2015.

19. L. Ying, E. Kang, and K. Neoh, "Covalent immobilization of glucose oxidase on microporous membranes prepared from poly (vinylidene fluoride) with grafted poly (acrylic acid) side 


\section{Chemical Engineering Research Bulletin 19(2017) 154-159}

chains," Journal of Membrane Science,vol. 208, pp. 361-374, 2002.

20. A.M. Vinogradov, V. Hugo Schmidt, G.F. Tuthill, and G.W. Bohannan, "Damping and electromechanical energy losses in the piezoelectric polymer PVDF," Mechanics of Materials,vol. 36, pp. 1007-1016, 2004.

21. M. Van Loosdrecht, J. Lyklema, W. Norde, G. Schraa, and A. Zehnder, "Electrophoretic mobility and hydrophobicity as a measured to predict the initial steps of bacterial adhesion," Applied and Environmental Microbiology,vol. 53, 1898-1901, 1987.

22. W. Norde, and J. Lyklema, "Protein adsorption and bacterial adhesion to solid surfaces: a colloidchemical approach," Colloid Surface, vol. 38, pp. 1-13, 1989.

23. I.W. Sutherland, "Biofilm exopolysaccharides: a strong and sticky framework," Microbiology, 147,pp. 3-9, 2001.
24. E. Karatan, and P. Watnick, "Signals, regulatory networks, and materials that build and break bacterial biofilms," Microbiology and Molecular Biology Reviews, vol. 73, pp. 310-347, 2009.

25. R. Steinberger, and P. Holden, "Macromolecular composition of unsaturated Pseudomonas aeruginosa biofilms with time and carbon source," Biofilms, vol. 1, pp. 37-47, 2004.

26. H.J. Busscher, A.H. Weerkamp, "Specific and non-specific interactions in bacterial adhesion to solid substrata," FEMS Microbiology Letters,vol. 46, pp. 165-173, 1987.

27. S. D'Souza, J. Melo, "A method for the preparation of coimmobilizates by adhesion using polyethylenimine," Enzyme and Microbiology Technology, vol. 13, pp. 508-511, 1991.

\section{Available online at http://www.banglajol.info/index.php/CERB}

Publisher: Department of Chemical Engineering, Bangladesh University of Engineering and Technology (BUET). Review \&Publication: A submitted original manuscript is taken into review only if the uniqueness is found to be more than $85 \%$ in plag-scanning and selected for publication by the complete acceptance from at least two reviewers out of three. Home Page: http://www.banglajol.info/index.php/CERB. Indexed by Chemical Abstract Service (CAS), CEABA-VtB, Google Scholar, Scopus and DOAJ 